\title{
Visual Objects and Universal Meanings: AIDS Posters and the Politics of Globalisation and History
}

\author{
CLAUDIA STEIN and ROGER COOTER*
}

\begin{abstract}
Drawing on recent visual and spatial turns in history writing, this paper considers AIDS posters from the perspective of their museum 'afterlife' as collected material objects. Museum spaces serve changing political and epistemological projects, and the visual objects they house are not immune from them. A recent globally themed exhibition of AIDS posters at an arts and crafts museum in Hamburg is cited in illustration. The exhibition also serves to draw attention to institutional continuities in collecting agendas. Revealed, contrary to postmodernist expectations, is how today's application of aesthetic display for the purpose of making 'global connections' does not radically break with the virtues and morals attached to the visual at the end of the nineteenth century. The historicisation of such objects needs to take into account this complicated mix of change and continuity in aesthetic concepts and political inscriptions. Otherwise, historians fall prey to seductive aesthetics without being aware of the politics of them. This article submits that aesthetics $i$ politics.
\end{abstract}

Keywords: AIDS Posters; Global History; Globalisation; Hamburg Museum für Kunst und Gewerbe; Historicism; Localism; Modernity; Museology; Nationalism; Politics of Aesthetics; Postmodernism; Visual Language

\section{Introduction}

Among striking developments in history writing towards the end of the twentieth century were the moves to the spatial and the visual in the reconstruction of historical consciousness. 'Global history', accelerated through American hype on 'globalisation', and 'visual culture studies' propelled by society's increasing reliance on visual communications, became fashionable projects. 'Global history', ${ }^{1}$ grounded in contemporary economics

(C) Claudia Stein and Roger Cooter, 2011.

*Dr Claudia Stein, History Department, Warwick University, Coventry CV4 7AL, UK. Email: claudia. stein@warwick.ac.uk

Professor Roger Cooter, The Wellcome Trust Centre for the History of Medicine at UCL,
183 Euston Road, London NW1 2BE, UK. Email: r.cooter@ucl.ac.uk

1 'Transnational', 'international' and 'world' are frequently used as synonyms; to avoid confusion we use 'global history' throughout this paper. 


\section{Claudia Stein and Roger Cooter}

and partly pitched in reaction to Western parochialism, came seriously to challenge nationalistic and structuralist approaches to history. ${ }^{2}$ At the same time, the 'pictorial turn', with its epistemological claim for vision as the prime sense in knowledge production, came to defy not only conventional history of art, but the status and value of the discipline of history itself. ${ }^{3}$ Wrestling with these turns proved enormously productive. In the history of medicine it led to foregrounding disease in its global dimension, revivifying, at the same time as challenging, older narratives on the 'world wide' spread of disease. ${ }^{4}$ In the history of science it led to heightened attention to visual representations in struggles over the production of scientific knowledge and authority. ${ }^{5}$ Both turnings did more than merely provide historians with exciting new conceptual frameworks for comprehending the past. As illustrated through the contemporaneous growth of a literature on the history of material objects in all their global distribution, they also helped broaden the range of objects deemed worthy of historical attention. ${ }^{6}$

\footnotetext{
${ }^{2}$ See Thomas Zeller, 'The Spatial Turn in History', German Historical Institute Bulletin, 35 (2004), 123-4; Denis Cosgrove, 'Landscape and Landschaft. Lecture delivered at the "Spatial Turn in History" Symposium German Historical Institute, February 19, 2004', German Historical Institute Bulletin, 35 (2004), 57-71; Doreen Massey, For space (London: Sage, 2005); George G. Iggers and Q. Edward Wang, A Global History of Modern Historiography (London: Pearson/Longman, 2008).

${ }^{3}$ Margaret Dikovitskaya, Visual Culture: The Study of the Visual After the Cultural Turn (Cambridge, MA: MIT Press, 2006); Marita Sturken and Lisa Cartwright, Practices of Looking: An Introduction to Visual Culture (Oxford: Oxford University Press, 2001); Nicholas Mirzoeff (ed.) The Visual Culture Reader (London: Routledge, 1998); idem, An Introduction to Visual Culture (London: Routledge, 1999); Barnard Malcolm, Approaches to Understanding Visual Culture, (Houndsmill: Palgrave, 2001); J.A. Walker and S. Chaplin, Visual Culture: An Introduction (Manchester: Manchester University Press, 1997); James Elkins, Visual Studies: A Skeptical Introduction (London: Routledge, 2003); Sarah Pink, The Future of Visual Anthropology: Engaging the Senses (Abingdon: Routledge, 2006). On the application of visual culture studies to historical study, see Gerhard Paul, Visual History: Ein Studienbuch (Berlin: Vendenhoech \& Ruprecht, 2006); Monika Dommann, 'Vom Bild zum Wissen: Eine Bestandsaufnahme wissenschaftshistorischer Bildforschung', Gesnerus, 61 (2004), 77-89; on the 'pictorial turn', coined by W.T. Mitchell in 1992, see Sybilla Nikolow and Lars Bluma, 'Science Images: Between Scientific Fields and the Public Sphere' in Bernd Hüppauf and Peter Weingart (eds), Science Images and Popular Images of the Sciences (London: Routledge, 2008), 33-51: 36.

${ }^{4}$ See, for example, Valeska Huber, 'The Unification of the Globe by Disease? The International Sanitary Conferences on Cholera,
}

1851-1894', Historical Journal, 49 (2006), 454-74; $c f$. Hans Zinser, Rats, Lice and History: Being a Study in Biography (Boston: Atlantic Monthly, 1935); William McNeill, Plagues and Peoples (Oxford: Blackwell, 1977).

${ }^{5}$ See, for example, Caroline A. Jones and Peter Galison (eds), Picturing Science, Producing Art, (New York: Routledge, 1998); Alex Soojung-Kim Pang, 'Visual Representation and Post-Constructivist History of Science', Historical Studies in the Physical and Biological Sciences, 28 (1997), 139-71; Bruno Latour and Peter Weibel (eds), Iconoclash: Beyond the Image Wars in Science, Religion and Art (Cambridge, MA: MIT Press, 2002); Lorraine Daston and Peter Galison, Objectivity (New York: Zone Books, 2007); Lisa Cartwright, Screening the Body: Tracing Medicine's Visual Culture (Minneapolis: University of Minnesota Press, 1995; Nick Hopwood, 'Pictures of Evolution and Charges of Fraud: Ernst Haeckel's Embryological Illustrations', Isis, 97 (2006), 260-301; Bert Hansen, Picturing Medical Progress from Pasteur to Polio: A History of Mass Media Images and Popular Attitudes in America (New Brunswick: Rutgers University Press, 2009); Bernard Lightman, 'The Visual Theology of Victorian Popularizers of Science: From Reverent Eye to Chemical Retina', Isis, 91 (2000), 651-80; Ann Shteir and Bernard Lightman (eds), Figuring it Out: Science, Gender, and Visual Culture (Hanover: Dartmouth College Press, 2006); Hüppauf and Weingart, op. cit. (note 3).

${ }^{6}$ For example, on the condom as a material object, see Nicole Vitellone, Object Matters: Condoms, Adolescence and Time (Manchester: Manchester University Press, 2008). For more historically focused studies on scientific and medical objects in global contexts, see Simon Schaffer, 'Instruments as Cargo in the China Trade', History of Science, 44 (2006), 217-46; Harold Cook, Matters of Exchange: Commerce, Medicine and Science in the Dutch Golden Age (New Haven: Yale University Press, 2007). 
This paper draws on these moves in relation to one particular material object that is both 'global' and visual: the AIDS poster. ${ }^{7}$ Their worldwide production from the mid1980s hugely reinvigorated the whole genre of the health poster and, according to one expert, restored the genre's original function as a communications medium. ${ }^{8}$ Certainly, as never before was so much money, aesthetic effort and psychological marketing put into this particular media on the part of voluntary bodies, national governments and international health agencies. ${ }^{9}$ Our concern, however, is with the wider conceptual frameworks that were mobilised to make these objects meaningful. In the 1980s and 1990s, as we have outlined elsewhere, a cohort of Western intellectuals concerned themselves with them along with other representations of AIDS in order to talk about the politics of identity. ${ }^{10}$ Those concerns, in turn, were linked to broader ones emerging at the time over the rights of citizens to equal access to health care, the privatisation of medicine, and the role of the international pharmaceutical industry in the commercialisation of health care. In this paper we focus on another aspect of these ephemeral mass-produced objects: not their 'active life' on the streets and in the corridors of learning but their 'afterlife' when they were turned into items to be collected, exchanged and stored in museums and archives. It is well known that the social life of material objects in such places is not the same as that of their initial culture of production, circulation and consumption. ${ }^{11}$ Museums and archives, like other depositories for images and artifacts, have particular collecting agendas and particular institutional and intellectual traditions into which new acquisitions are fitted. They also inhabit the present, embracing wider conceptual contexts that serve further to shape the organisation and meaning of their artifacts.

Here, we explore one such 'afterlife' for AIDS posters: an exhibition entitled 'Against Aids: Posters from Around the World', which was held at the Museum für

\footnotetext{
${ }^{7}$ Throughout this paper we use 'AIDS posters' as shorthand for 'HIV/AIDS posters'. This is the generic terms used by vendors, collectors and exhibiters for posters relating not just to AIDS, specifically, and the need for precautionary measures such as condoms, but also, to issues such as homophobia. Our use of 'poster' follows Harold Hutchinson, The Poster: An Illustrated History from 1860 (London: Studio Vista, 1968), 1: '[E]ssentially a large announcement, usually with a pictorial element, usually printed on paper and usually displayed on a wall or billboard to the general public.' However, the meaning of 'the public' in this connection was to some extent challenged by AIDS posters (see below note 72).

${ }^{8}$ Felix Studinka, 'Foreword' in Poster Collection: Visual Strategies Against AIDS, International AIDS Prevention Posters (Zurich: Museum für Gestaltung Zurich and Lars Muller Publishers, 2002), 5.

${ }^{9}$ For illustrations of AIDS posters see: Roger Cooter and Claudia Stein, 'Protect Yourself' in Public Health Campaigns: Getting the Message Across (Geneva: World Health Organisation, 2009), 66-88; Hugh Rigby and Susan Leibtag, HardWare: The Art of Prevention (Edmonton: Quon Editions, 1994);
}

Becky Field et al., Promoting Safer Sex: A History of the Health Education Authority's Mass Media Campaigns on HIV, AIDS and Sexual Health, 1987-1996 (London: Health Education Authority, 1997); Becky Field and Kaye Wellings, Stopping AIDS: AIDS/HIV Public Education and the Mass Media in Europe (London: Longman, 1996); Jürgen Döring (ed.), Gefühlsecht: Graphikdesign der 90er Jahre (Hamburg: Museum für Kunst und Gewerbe, 1996); Edition Braus, 'Aids Plakate International Bildsammlung 1985-1997', a CD-ROM produced by Stiftung NeoCortex for Medizinische Fakultät der Universität, Basel (n.d.); and the websites of the institutions mentioned below (note 16) holding the largest collections of AIDS posters.

${ }^{10}$ Roger Cooter and Claudia Stein, 'Coming into Focus: Posters, Power, and Visual Culture in the History of Medicine', Medizinhistorisches Journal, 42 (2007), 180-209.

${ }^{11}$ Constance Classen and David Howes, 'The Museum as Sensescape: Western Sensibilities and Indigenous Artifacts', in Elizabeth Edwards, C. Gosden and R. Phillips (eds), Sensible Objects: Colonialism, Museums and Material Culture (Oxford: Berg, 2006), 200. 


\section{Claudia Stein and Roger Cooter}

Kunst und Gewerbe in Hamburg between February and April 2006. We do not aspire to make causal claims for the 'importance' or 'impact' of the exhibition; our interest in it is, rather, as an illustration of the more general trend towards the 'global' rearrangement of material in museums by the twenty-first century. The Museum für Kunst und Gewerbe was founded in 1877 in a spirit of aesthetic modernism and German nationalism, and by the 1890 s was host one of Germany's largest and most prestigious poster collections. It was intended as a place to celebrate 'the people's' arts and crafts, much like the South Kensington Museum in London, established in 1852 and renamed the Victoria and Albert Museum in 1899 at the height of British jingoism. As at the Hamburg Museum für Kunst und Gewerbe, so at the Victoria and Albert Museum over the past few decades, objects have been reorganised for exhibitions accentuating 'the global'.

The representation of AIDS posters at the Hamburg exhibition provides us with a means to discuss the politics of such 'global assemblages'. ${ }^{12}$ On the one hand, it permits us to draw out the inherent contradictions and tensions that can be involved in any such institutional mobilisation of the concept of 'the unity of the globe'. ${ }^{13}$ On the other, it allows us to underline important continuities hidden under the more apparent or insisted upon 'discontinuities' between national and global discourses, and between modern and postmodern politics of aesthetics-continuities rooted, we argue, in shared aesthetic values. ${ }^{14}$ As important, the example permits us to reflect on how the discourse of the global affects the work of historians using material objects in their constructions of historical consciousness. As these aims and objectives should suggest, we are not concerned here with how viewers might have responded to the images or to the exhibition as a whole (an almost impossible task given the uniqueness of individual psychology and experience). ${ }^{15}$ Nor are we interested in providing a walkthrough critique of the exhibition; our main interest is in the historical context of the Museum and how this bears on the politics of aesthetics implicated in its exhibition of AIDS posters.

\footnotetext{
${ }^{12}$ Aihwa Ong and Stephen J. Collier (eds), Global Assemblages: Technology, Politics, and Ethics as Anthropological Problems (Oxford: Blackwell, 2005).

${ }^{13}$ We do not therefore engage here with the claim made by various theorists, that it is now impossible to talk of AIDS/HIV without referring to mutually metaphorised models and theories of globalisation. According to some, it is now impossible to even conceptualise 'globalisation' without also thinking in terms of the AIDS pandemic. See Dennis Altman, 'Globalisation and the AIDS Industry', Contemporary Politics, 4 (1998), 233-45; Richard Brock, 'An "Onerous Citizenship": Globalisation, Cultural Flows and the HIV/AIDS Pandemic in Hari Kunzru's Transmission', Journal of Postcolonial Writing, 44 (2008), 379-90.
}

\footnotetext{
${ }^{14} C f$. Jacques Rancière, The Politics of Aesthetics, Gabriel Rockhill (trans. and intr.), (London: Continuum, 2006). Throughout this paper we adhere to the crucial distinction established by Paul Forman between 'postmodernism' as a body of thought critical of modernity from 'postmodernity' as an era in which we still live. Further, we follow him on the fallacy of thinking the former the cause of the latter: '(Re)cognizing Postmodernity: Helps for Historians-of Science Especially', Berichte zur Wissenschaftsgeschichte, 33 (2010), 1-19.

${ }^{15}$ We reflect on this problem in another paper: Roger Cooter and Claudia Stein, 'Visual Imagery and Epidemics in the Twentieth Century,' in David Serlin (ed.), Imagining Illness : Public Health and Visual Culture (Minneapolis: University of Minnesota Press, 2011).
} 


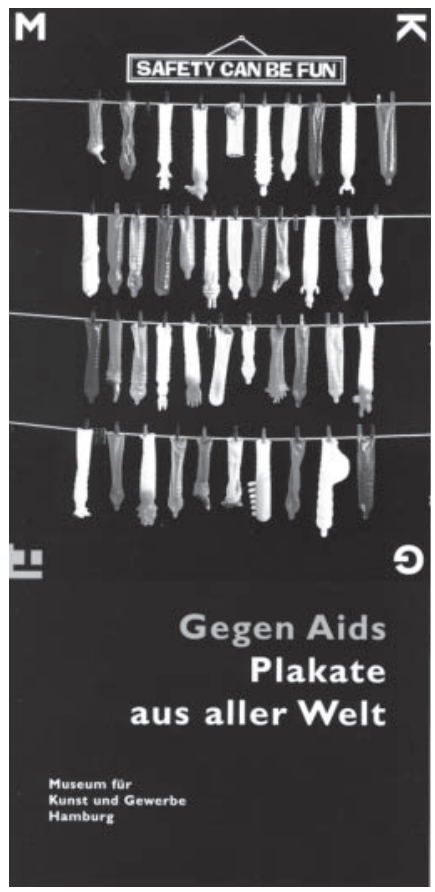

Figure 1: The leaflet $(10 \times 21 \mathrm{~cm})$ for 'Against Aids: Posters from around the World', Museum für Kunst and Gewerbe, Hamburg, 2006. By permission of the Museum für Kunst and Gewerbe, Hamburg.

\section{The Hamburg Exhibition}

'Against Aids: Posters from Around the World' was a modest, low-budget affair. Primarily, it was staged in order to exploit the Museum's recent acquisition of over a thousand HIV/AIDS and safe sex posters from a private dealer, a purchase that enabled it to join the club of institutions harbouring such collections. ${ }^{16}$ The organisers of the exhibition selected only a hundred of the posters to display, choosing those that were most visually arresting, and others that, even after three decades in some cases,

\footnotetext{
${ }^{16}$ The Wellcome Library, London; the Library of the National Institute of Health, Bethesda, Maryland; and the Deutsches Hygiene Museum, Dresden. A collection of 625 AIDS posters from 44 countries is held at UCLA, and can be accessed online: http://digital.library.ucla.edu/ Aidsposters/. There is perhaps another paper to be written on the interior politics of such purchases within economic climates of retrenchment, and on the demands this then places on the kind of advertising deployed for the exhibitions-in the Hamburg case a website image of a punchy
}

young woman conveying gender and alternative life styles - and on the actual display of the objects in the interest of maximising the public passing through the turnstiles. This is not our concern here, though it might be noted that financial stringencies connect to the contemporaneous articulation of a wider problematic on the purpose and function of museums internationally, on which see James Cuno, Whose Muse? Art Museums and the Public Trust (Princeton: Princeton University Press, 2004). 


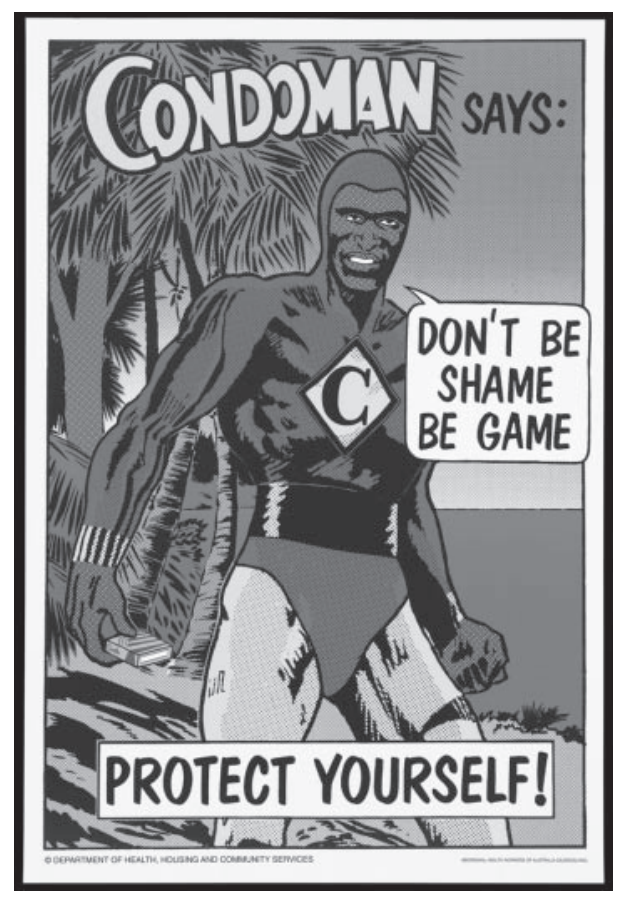

Figure 2: Issued by the Commonwealth Department of Community Services, Aboriginal Health Workers of Australia (Queensland), $1991(41 \times 28 \mathrm{~cm})$. Courtesy of the Wellcome Library, London. This poster was reproduced in several countries with the English translated.

still had the power to shock, titillate, and/or amuse (such as that used on the front of the flyer for the exhibition, Figure 1, or 'condoman', Figure 2). In part to enhance these effects, realist anti-homophobic posters (Figure 3), were mixed with erotic 'body-beautiful' ones, such as 'Semen Kit' (Figure 4). Posters were also connected through novel imagistic and ironic associations. 'Semen Kit', for example, joined nautical space with a poster of a condom disguised as a life-saving ring, ${ }^{17}$ which, in turn, was hung alongside a Russian poster advert for rubber tyres. These striking juxtapositions were intended to reveal the variety of aesthetic choices that governments, charities, commercial bodies, and private artists employed in their efforts to inform the public of the threat of HIV/AIDS and incite onlookers to ethical behaviour (safer sex). Dramatically, at the entrance to the exhibition, the visitor was confronted with a full billboard-size reproduction of Oliviero Toscani's iconic image of 1992: his re-conception of the prize-winning photograph from Life depicting the death of the American AIDS activist David Kirby, turned into an advertisement for the United

\footnotetext{
${ }^{17}$ Designed by Yossi Lemel of Israel and photographed by G. Korisky, 1993, reproduced in Döring, op. cit. (note 9), 145.
} 


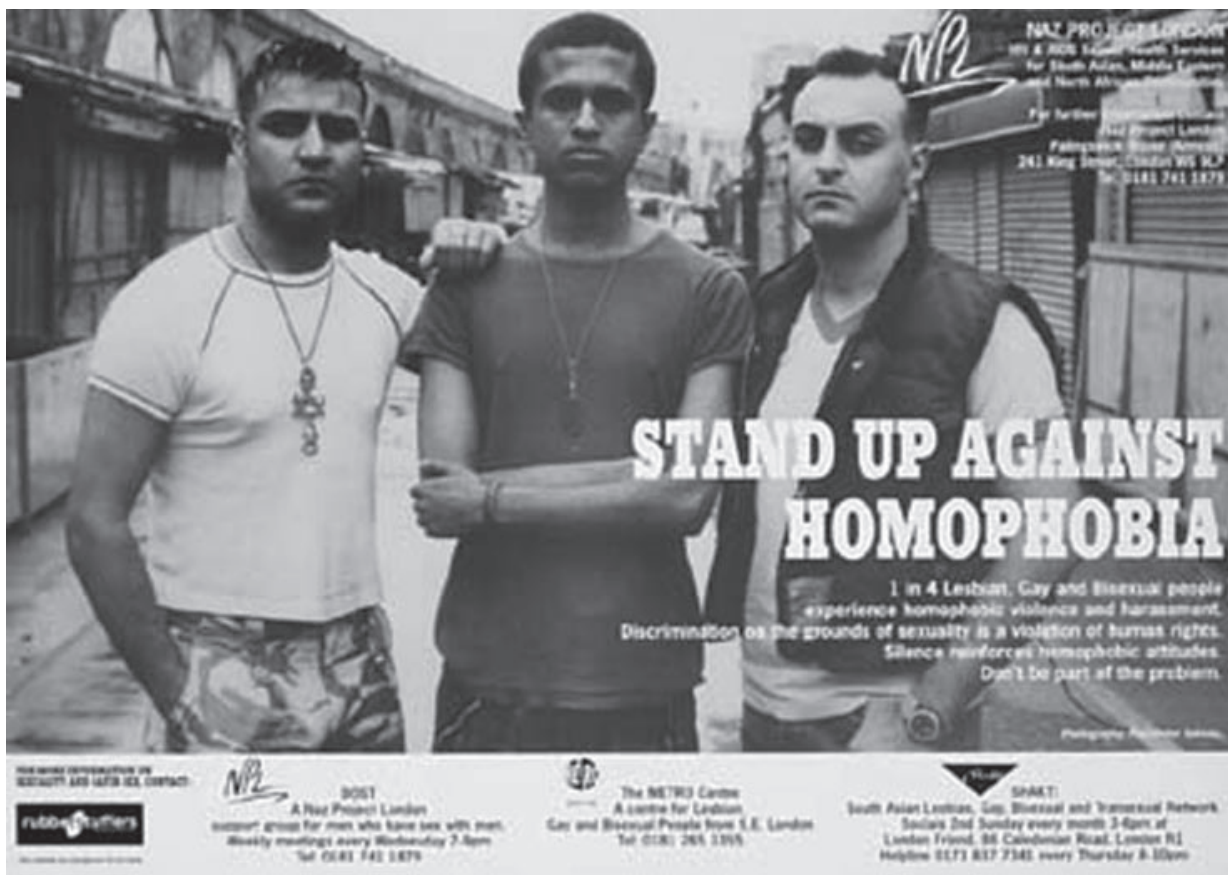

Figure 3: Produced by Terrence Higgins Trust, 1999. By permission of the Terrence Higgins Trust.

Colours of Benetton (Figure 5). ${ }^{18}$ Other less dramatic images played on popular solidarities around AIDS, as prefigured in the socially integrative 'Against Aids' in the title of the exhibition. These images could serve to counter any charge that might be levelled at the Museum for its use of the more erotic and more humorous and ironic ones, namely, that it was denying the pain and suffering of HIV/AIDS victims, or trivialising the world's most devastating disease. 'Against Aids' was also literalised in the predominance of posters promoting the use of condoms. It was through the display of these posters in particular that the exhibition sought to exemplify regional variety and similarities in aesthetic styles. Condoms, the viewer might come to see, were globally an unambiguous symbol for, and the warning against, unsafe sex. ${ }^{19}$

\footnotetext{
${ }^{18}$ The black-and-white photo entitled 'Final Moment', by the American photographer Therese Frare, appeared in Life in November 1990. See Oliviero Toscani, Die Werbung ist ein lächelndes Aas, Barbara Neeb (trans.), (Mannheim: Fisher Taschenbuch Verlag, 2000), 58; and Cooter and Stein, op. cit. (note 10); and idem, op. cit. (note 15).

${ }^{19}$ On the past and present ambiguous status of the condom as both a legal and morally approved hygienic product, and as an illegal and morally disapproved means to birth control, See Paula
}

Treichler and Kelly Gates, “"When Pirates Feast...Who Pays?" The Pirate Figure in Trojan Brand Condom Advertisements, 1926-1932', unpublished paper presented at the American Association for the History of Medicine 83rd Conference, Rochester, Minnesota, 30 April 2010, and see http://www.chicagohumanities.org/en/ Genres/History/2010-History-of-the-Condom.aspx, accessed 12 October 2010. See also Vitellone, op cit. (note 6). 


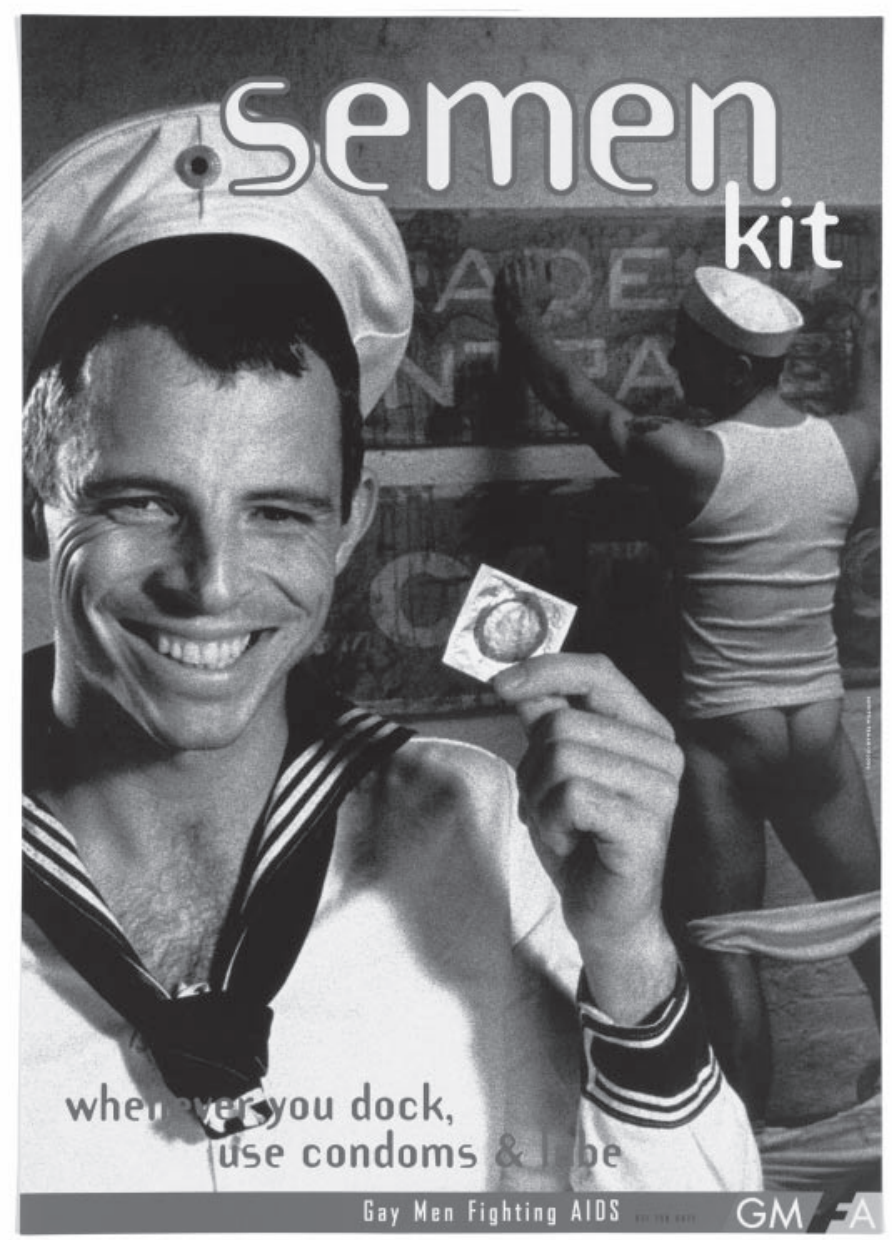

Figure 4: Issued by 'Gay Men Fighting AIDS', London, $1994(59 \times 42 \mathrm{~cm})$, Hywel Williams photographer. Courtesy of the Wellcome Library, London. The image was reproduced on a 15 cm card, which was handed out at the Gay Pride festival in July 1994. The text on the card mentions the UK government's poor funding of safe sex campaigns and Parliament's homophobic reaction to the proposal of an equal age of consent of 16 for both hetero- and homosexuals. 


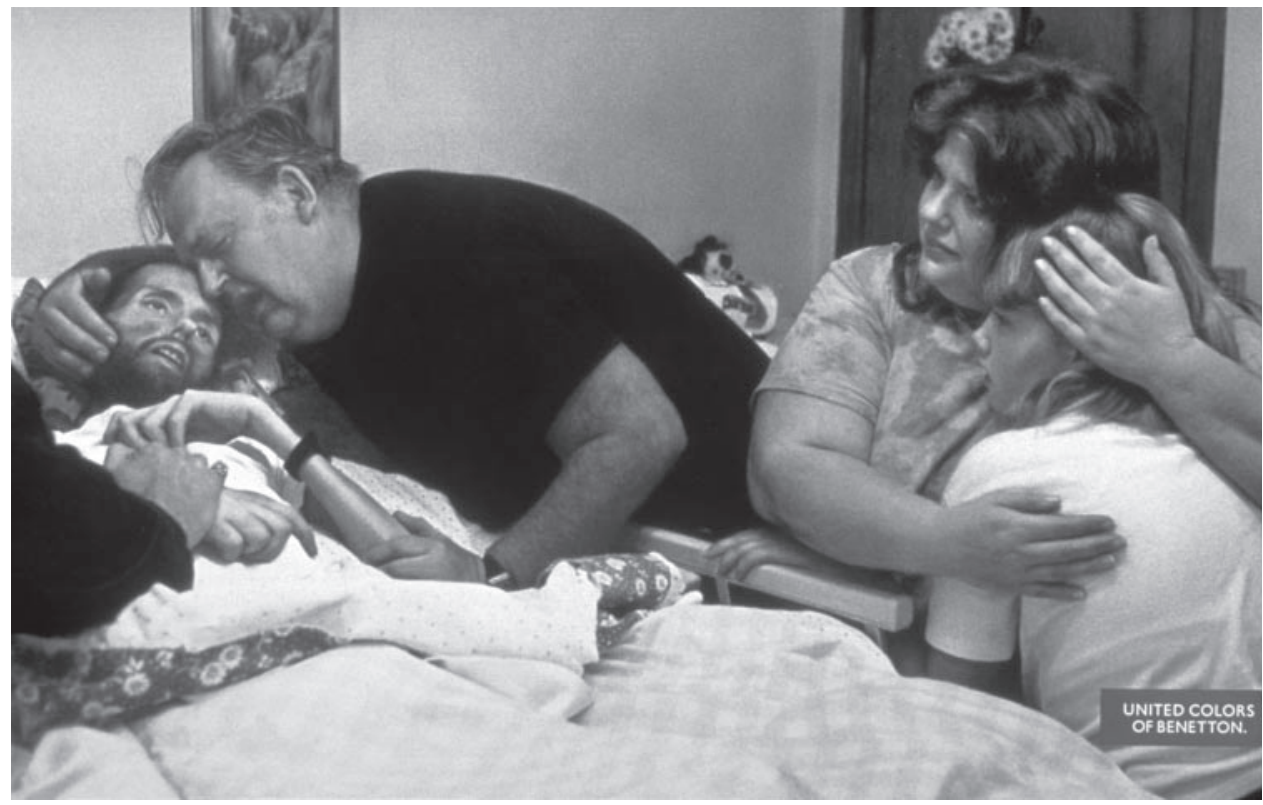

Figure 5: Oliviero Toscani's 1992 billboard image of the death of David Kirby for Benetton's 'Shock of Reality' advertising campaign. By permission of the United Colors of Benetton.

\section{Aesthetic Framing}

Although a flyer (Figure 1), but no catalogue was produced for the show, the aesthetic and intellectual motives behind it are discernable through the catalogue that accompanied a much larger exhibition of posters held at the Museum in 1996 (which was curated by the same person, Jürgen Döring, and displayed some of same posters). ${ }^{20}$ The 1996 exhibition marked the centenary of the Museum's first-ever exhibition of posters - a late nineteenth century entertainment that was in fact the first of its kind in Germany and one of the first in Europe. ${ }^{21}$ In many ways the 1996 exhibition was faithful to that of 1896, its agenda being more or less the same as that articulated by the main advocate and co-founder of the Museum für Kunst und Gewerbe,

${ }^{20}$ Döring, op. cit. (note 9), 13. The 1996 exhibition was partly organised around HIV/AIDS; its other three themes were 'Heads', 'Bodies' and 'Human Rights'.

${ }^{21}$ The 1896 exhibition took place three years before Roger Marx formulated the idea for such exhibitions in the journal Les Maitres de l'Affiche, and proposed a Musée moderne de l'Affiche illustrée: Margaret Timmers (ed.), The Power of the Poster (London: V\&A Publications, 1998), 12-13. On the late nineteenth-century poster movement in Germany, see Jeremy Aynsley, Graphic Design in Germany 1890-1945 (London: Thames and Hudson, 2000), 30. Aynsley mistakenly dates the Hamburg exhibition as 1893 (p.31), and misattributes Das Moderne Plakat by the curator of the Dresden Museum für Kunst und Gewerbe (1897) as the first German book on posters (pp.31, 35; the first such being that by Justus Brinkmann cited in note 23 below). 


\section{Claudia Stein and Roger Cooter}

the Hamburg lawyer and art critic Justus Brinckmann (1843-1915). ${ }^{22}$ In his catalogue for the 1896 exhibition, Brinckmann opined that posters and their display in museums and galleries performed the 'ethical task' of elevating the masses to aesthetic appreciation:

Art should be accessible to everyone. It should bring elevation and joy to all; not only to those who buy it or have the time to visit art galleries. In order to fulfil this purpose art has to go on the street, and has to cross - as if by accident - the path of the many thousands going to work who have neither time nor money to devote to it otherwise. ${ }^{23}$

These were not the only politics in the 1896 exhibition with resonance for the one in 1996. The wider context at the end of the nineteenth century was that of flourishing national rivalries as well as attitudes to competition as a virtue in itself-be it between regional institutions, or between the military might and/or levels of 'civilisation' of different nation-states. The posters in the 1896 exhibition, from Italy, France, Russia, the USA and elsewhere, were organised accordingly and, typical of most exhibitions at the time displaying products from different countries, were competitively judged by an international panel. The exhibition thus served to cohere national identities at the same time as sell the ideology of competition along with the virtues of the products of mass-production for mass (visual) consumption. More than this, while on the one hand the 1896 exhibition promoted the promise of democracy embedded in the notion of arts and crafts 'by and for the people', uniting people through aesthetics education, on the other, it sold an élitist aesthetic ethics that simultaneously challenged traditional élitist views of what constitutes 'art' and who 'properly' can access and comment on it. ${ }^{24}$

A century later many of Brinckmann's views were dusted off. Jürgen Döring, the curator of the 1996 exhibition (and subsequently the 2006 one) similarly revelled in

\footnotetext{
${ }^{22}$ For cultural politics in Hamburg and Brinckmann's role as a patron of the arts, see Carolyn Kay, Art and the German Bourgeoisie: Alfred Lichtwark and modern painting in Hamburg, 1886-1914 (Toronto: University of Toronto Press, 2002); on Brinckmann, see Heinz Spielmann, Justus Brinckmann (Hamburg: Ellert und Richter, 2002).

${ }^{23}$ Justus Brinckmann, Katalog der PlakatAusstellung: Hamburg 1896 Museum für Kunst und Gewerbe (Hamburg: Lütcke \& Wulff E. H.

Senatsbuchdruckerei, 1896), 92. Similar motives lay behind 'Mr Robert Newman's Promenade Concerts' (later known as the 'London Proms') to bring 'quality' music to the masses at low cost (1 shilling per concert), the first of which was held in August 1895. For contemporary expression of similar views in Germany and Britain, see Detlef Hoffmann, 'The German Art Museum and the History of the Nation,' in Daniel J. Sherman and Irit Rogoff (eds), Museum Culture: Histories, Discourses, Spectacles (Minneapolis: University of Minnesota Press, 1994), 3-21; and Seth Koven, 'The Whitechapel Picture
}

\begin{abstract}
Exhibition and the Politics of Seeing', in Sherman and Rogoff, idem, 22-48. A further part of the purpose of poster exhibitions was to educate people to the technology of graphic design. For example, in 1931, the Victoria and Albert Museum's Exhibition of British and Foreign Posters asserted that 'this Museum is concerned less with the economic aspect, the publicity value, of the poster than with its technical method and the artistic impulse which finds expression in the special means employed. From a Museum point of view, therefore, this Exhibition of Posters might almost equally well be described as an exhibition of lithographs and of lithographic

technique.' Quoted in Timmers, op. cit. (note 21), 19.

${ }^{24}$ On the systematic collection of posters by national institutions as evidence of democratised and populist culture, and as challenge to the traditional arts, see Aynsley, op. cit. (note 21), 30ff, and Jim Aulich and John Hewitt, Seduction or Instruction?: First World War Posters in Britain and Europe (Manchester: Manchester University Press, 2007), 11-34.
\end{abstract}


the non-élitist engagement of poster art, at the same time as celebrating the particular aesthetic distinction that Brinckmann drew between mundane commercial advertising and sophisticated poster design. ${ }^{25}$ The 1996 exhibition visually illustrated this difference by juxtaposing examples of each. Above all, Döring celebrated and reproduced Brinckmann's ethical mission to teach people how to appreciate and enjoy the visual world through a better understanding of its underlying aesthetic principles and techniques of production. ${ }^{26}$ This ethical educational work of the poster is all the more important today, he argued in the catalogue, because the fine arts have lost the main task they had when Brinckmann was living, namely, to interpret the world in its visual parts and provide the onlooker with an edifying understanding of it. ${ }^{27}$

The 2006 exhibition of AIDS posters was conceived in the same intellectual framework, according to Döring. ${ }^{28}$ It, too, was intended to elicit an emotional response from the viewer and, from that, heighten their sensitivity to art. ${ }^{29}$ But while Brinkmann in his day had looked forward to a brighter future for the poster and its onlookers in museums such as the Kunst und Gewerbe in Hamburg, Döring and his colleagues found it hard to be quite so optimistic. In their view-as maintained in the catalogue for the 1996 exhibition - the general quality of the visual language of posters had dramatically decreased due to the increasing flood of pictures in everyday life. Discriminating aesthetic appreciation, they felt, was less and less in evidence in contemporary culture because modern education failed to teach the classics and its iconography. Consequently, despite the fact that posters were intimately a part of the revolution in graphic design and design technology of the $1980 \mathrm{~s}$ and $1990 \mathrm{~s},{ }^{30}$ they had become impoverished-superficial, because they could no longer be 'properly' designed or read. Hence these objects reflected a lack of social and moral responsibility. The apparent proof of this lay in the popular media's focus on the human body or, more precisely, on superficial beauty and 'feelings' around the human body. According to Döring and his colleagues this was the Zeitgeist of our times that 'exceeds rational understanding'. 31 Today's fashionable heroes hardly transmit any moral values, they lamented; indeed, they did the opposite-dissipating, through preoccupations with individual self-fulfilment and superficial gratification, the cannon of Christian ethics and traditions of virtue behind 'good art'. 32

AIDS posters apparently shared this fate in having behind them no shared aesthetic appreciation. According to the 1996 catalogue, they could communicate no meaningful

\footnotetext{
${ }^{25}$ Döring, op. cit. (note 9), especially 187.

${ }^{26}$ Ibid., $13-14$.

${ }^{27}$ Ibid., 13.

${ }^{28}$ Interview 26 July 2010.

${ }^{29}$ Interview (CS) with the assistant curator of the exhibition, Hendrik Lunganini, 21 June 2006.

${ }^{30}$ Richard Hollis, Graphic Design: A Concise History (London: Thames and Hudson, 1994); Jeremy Myerson and Graham Vickers, Rewind: Forty Years of Design and Advertising (London: Phaidon Press, 2002).

${ }^{31}$ Döring, op. cit. (note 9), 15. Such comments-including the idea of Zeitgeist—are
}

strikingly resonant of those on 'degenerate art' by the Nazis; see Stephanie Barron (ed.), 'Degenerate Art': The Fate of the Avant-Garde in Nazi Germany (New York: Harry Abrams, 1991).

${ }^{32}$ Döring, ibid. Another way to interpret these views is in terms of 'epistemic virtues', as elaborated by Daston and Galison, op. cit. (note 5). As Daston and Galison insist, within the culture of science and in cultural more generally, old epistemic virtues are never simply discarded or confronted head-on by new ones, but rather, are retained often long after the creation of new ones 


\section{Claudia Stein and Roger Cooter}

visual language for the deadly disease they referred to because the health educationalists who issued them were themselves unable to formulate one. Hence, the iconography of AIDS posters appealed predominantly only to the feelings of onlookers. All that could really be said in their favour was that they sponsored a positive moral practice, namely caution against the spread of HIV: 'the onlooker feels attracted by the picture and decides to use a condom. ${ }^{33}$ Although it seems odd that the curators of the Museum für Kunst und Gewerbe disdained the very objects they were celebrating, they justified themselves on the grounds that such posters were expressive 'of their times' and therefore wholly within the remit of an institution whose agenda was to archive and exhibit the art of the streets and the people. By the 2006 exhibition, 'the times' were global, and hence a new justification was established through the parade of moral values within that discourse.

In maintaining that contemporary culture and advertising were saturating the world with meaningless, morally deprived, corporeally fixated images, the curators of the Museum für Kunst und Gewerbe were maintaining a distinctly 'modernist' - as opposed to postmodernist-view of 'art'. In fact, in believing that the mechanics of perception operated along the lines of emotional attraction, followed by rational thought, and then enlightened responsible behaviour, they were following nineteenth-century notions of the physiology of seeing and sense perception. ${ }^{34}$ They were also assuming that onlookers were simply passive vessels for ethical education in visual good taste and, moreover, that good taste was the highest form of human awareness. Interestingly, in many of these respects - as well as in connection with the understanding of disease-they were sharing an outlook with one of the few intellectuals in the twentieth century ever to provide sustained commentary on posters, the late Susan Sontag (1933-2004) - despite the fact that Sontag, as a theorist, was to their left in embracing the Marxism of the Frankfurt School of Critical Theory. ${ }^{35}$

Sontag's views were made clear in 1970 in 'Posters: Advertisement, Art, Political Artifact, Commodity'. ${ }^{36}$ Posters, inhabiting the 'low end' of 'high art', she explained, originated 'in the effort of expanding capitalist productivity to sell surplus or luxury goods.' They could not exist:

[B]efore the specific historic conditions of modern capitalism. Sociologically, the advent of the poster reflects the development of an industrialised economy whose goal is ever-increasing mass consumption, and (somewhat later, when posters turned political) of the modern secular centralised nation-state, with its peculiarly diffuse conception of ideological consensus and its rhetoric of mass political participation. ${ }^{37}$

\footnotetext{
${ }^{33}$ Döring, ibid., 16.

${ }^{34}$ Jonathan Crary, Suspensions of Perception: Attention, Spectacle and Modern Culture (Cambridge, MA: MIT Press, 2000).

${ }^{35}$ For Sontag's intellectual and political context, see Sturken and Cartwright, op. cit. (note 3), 151-78. On the Frankfurt School, see Martin Jay, The Dialectical Imagination: A History of the Frankfurt
}

School and the Institute of Social Research, 1923-50 (London: Heinemann, 1973).

${ }^{36}$ Susan Sontag, 'Posters: Advertisement, Art, Political Artifact, Commodity', introductory essay to Dugald Stermer, The Art of Revolution: 96 posters from Cuba (London: Pall Mall Press, 1970), vii-xxiii: viii. The following comments on Sontag are drawn from Cooter and Stein, op. cit., (note 10), 188-90.

${ }^{37}$ Sontag, ibid., viii. 
Posters thus served the purpose of aggressively pushing consumption or, in politics, of selling national id entities and ideologies. Indeed, they presupposed 'the modern concept of the public' as well as 'the modern concept of public space-as a theatre of persuasion. ${ }^{38}$ This regard of posters, as 'aim[ing] to seduce, to exhort, to sell, to educate, to convince, to appeal', ${ }^{39}$ was predicated on a view of advertising (of any sort) as psychologically dangerous. For Sontag, posters blinded people to the real world, a view (shared by the curators of Hamburg's Museum fur Kunst und Gewerbe) that presupposes some unmediated or 'pure' form of underlying reality. According to this view, one has only to break through the constructions mediated by language or by images to experience a direct understanding of the world though senses and perceptions.

Although Sontag had no reason to comment on health posters until she came to write AIDS and its Metaphors in 1988, her thinking on them was indistinguishable from her earlier thoughts. AIDS posters, she maintained, indict the ideology of consumer capitalism that celebrates recreational risk-free sexuality in the name of individual liberty. ${ }^{40}$ Furthermore, as in her Illness as Metaphor (1978), there was no doubt about the biological essence of such a disease. Just as posters mediated false-consciousness, so behind the 'distorting' metaphors of any widely feared disease there lurked a 'real' entity. One had only to strip away the metaphors to get at the underlying value-neutral, non-stigmatising nature of any disease. ${ }^{41}$ The organisers of the exhibitions of AIDS posters at Hamburg's Museum für Kunst und Gewerbe similarly believed AIDS to be 'real'-that is, to be a universal 'medical' problem that was simply yet to be solved. As if to underline this understanding of HIV/AIDS as medical and nothing more, the 2006 exhibition was accompanied by health education information issued by various private and national HIV/AIDS agencies. Significantly, in both the flyer for the 2006 exhibition and in the section on AIDS in the 1996 catalogue, a medical discussion of HIV/AIDS preceded that on the aesthetics of the posters. Thus, a distinctly modernist view of art was accompanied by a distinctly modernist, as opposed to postmodernist, view of science and medicine as unquestionably superior forms of consciousness and practice, even to art.

\section{Re-picturing AIDS}

How people interacted with AIDS posters during the images' active life on the streets - on buses, billboards, underground trains, and so on-and how the power and fear of HIV/AIDS operated in relation to identity were simply not parts of the 2006 exhibition in Hamburg. Through the literal framing of the posters, their hanging according to the conventions of art galleries, their arrangement (three or four to a single wall), and the choice of them in terms of the quality of their visual language (Bildersprache), the

\footnotetext{
${ }^{38}$ Ibid., vii.

${ }^{39}$ Ibid., viii.

${ }^{40}$ Susan Sontag, AIDS and Its Metaphors

(London: Penguin, 1990), 75ff.

${ }^{41}$ For a critique of Sontag's use of the metaphor of disease, see Allan Brandt, No Magic Bullet: A
}

Social History of Venereal Disease in the United States since 1880 (New York: Oxford University Press, 1985) 193, n.7; idem, 'Emerging Themes in the History of Medicine', The Milbank Quarterly, 69 (1991), 199-214: 204. 


\section{Claudia Stein and Roger Cooter}

organisers denuded them of the local contexts in which they were created and in which they were engaged with politically, intellectually and emotionally. This absenting can probably be illustrated by paying close attention to the history of any one of the posters in the exhibition. Here, we focus on only a few of them to illustrate the point: 'Semen Kit' (Figure 4), 'Stand Up Against Homophobia' (Figure 3), and Toscani's advertisement for Benetton (Figure 5).

The first two of these were among the five British examples of posters in the exhibition. Both were issued by HIV/AIDS charities (as were the other three British examples in the show), and were relatively recent. 'Semen Kit' (1994) was produced by the GMFA [Gay Men Fighting AIDS] (established in 1992), whilst 'Stand Up Against Homophobia' (1999) was distributed by the Terrence Higgins Trust (established in 1982 and, by the 1990s, Britain's leading HIV and sexual health charity). That they were not issued by the state is important, for they were in fact conveying messages alternative to it. In 1986, when Thatcher's government announced its intention to spend $£ 20$ million over the next twelve months on HIV/AIDS health 'information', and commissioned the advertising agency TBWA to undertake it, the resulting 'Iceberg' and 'Tombstone' images were crafted to sell a health message to a general audience and to meet the government's inflated interest in family values, heterosexual sex, and nationhood. ${ }^{42}$ Condoms were not then in the frame, nor were gay men, and nor was 'the global'. The story of how the 'patriotic heterosexual imaging ${ }^{43}$ began to be turned around in the 1990s need not concern us here. ${ }^{44}$ As in most Western countries, it was gay men-the first victims of the disease-who initially confronted the benign, sexually prudish and denying images of the establishment, and then inverted the anti-liberal homophobic rhetoric generated by 'the gay plague' in celebration of their own collective identity ('the gay community'). It only needs observing that in the UK this development was significantly different from elsewhere; bearing upon it were the particularities of social and cultural traditions as well as prevailing political, medical and legal circumstances. Pre-existing affirmative representation in the public media of 'gays' were far less pronounced than in some other places, while the ability of the tabloid press and the Conservative government of the day to stir homophobia was greater. ${ }^{45}$ Prime Minister Margaret Thatcher's homophobic legislation of 1988 (Section 28 of the Local Government Act forbidding the

\footnotetext{
${ }^{42}$ For the images and historical commentary, see http://www.avert.org/his87_92.htm.

${ }^{43}$ Simon Watney, Policing Desire: Pornography, AIDS and the Media, [1987] $3^{\text {rd }}$ edn (London: Cassell, 1997), 15-16.

${ }^{44} \mathrm{~A}$ good account is provided by Matt Cook, 'From Gay Reform to Gaydar, 1967-2006' in Matt Cook et al. (eds), A Gay History of Britain: Love and Sex Between Men Since the Middle Ages (Oxford: Greenwood World Publishing, 2007), 179-214.

${ }^{45}$ Cook, 'The 1980s Backlash', ibid, 204-14. Commenting on this backlash, Watney, op. cit. (note 43), 18, quotes Dennis Altman, "'the risk to gay identity seems greater in countries such as Great
}

Britain and the Irish Republic, where the gay movement has less legitimacy and seems less able to withstand a new ideological onslaught, backed by real fears and dangers." We are now facing that onslaught... which threatens not only our health but our very social identity, as the term "gay", wretched away from the older pejorative discourse of "homosexuality", is reloaded before our very eyes with all the familiar connotations of effeminacy, contagion and degeneracy.' On representations of gay men in the UK media at this time, see Keith Howell, Broadcasting It: An Encyclopedia in Film, Radio and TV in the UK, 1923-1993 (London: Cassell, 1993). 
promotion of homosexuality) in particular, did much for heightening alterity, struggle and confrontation.

'Semen Kit' and 'Stand Up Against Homophobia' exemplify and reflect this particular legacy. Yet it was precisely these features that the Hamburg exhibition eclipsed by having the images hung alongside foreign advertisements and alongside AIDS posters from China and elsewhere. The exhibition thereby performed not for the struggle for gay identity within a national context, but for world solidarity. 'Stand Up Against Homophobia', by virtue of being both a product of 1999, and by presenting HIV/AIDS as a part of a wider social issue, served in itself to mask the historical significance of these images. 'Semen Kit' performed similarly through its play to a would-be unproblematic history of overt sexual behaviour among men (inconised in the image of the sailor), and by its appropriation from some American AIDS posters of the by then more-than-a-decadeold image of the gay 'body beautiful'. ${ }^{46}$ That gay men in Britain, well into the 1990s, were still struggling for a viable visual public identity could not be guessed from the hanging of this poster at Hamburg. Nor could it be known from either of these images that the changes in gay identity that occurred in Britain in the 1990s were, in part, largely attributable to the uptake of a slick visual language borrowed from the culture of Madison Avenue-driven international advertising - the same visual language, from the same source, that was simultaneously taken up by Thatcher and other politicians around the world in electioneering.

But it was not only governments and gays in the 1980s and 1990s who struggled to capture the meaning of AIDS; so too did western medicine. It was its lack of success at turning AIDS into a meaningful scientific category that, in fact, opened the medical profession to pointed confrontation, and opened up AIDS to the visual politics of identity. In effect, through AIDS, and in particular through the early debate over whether HIV caused AIDS, the medical profession was pulled off its pulpit as the authoritative arbiter of modern secular identity. ${ }^{47}$ Arguably, Toscani's poster advertisement for Benetton reflects this by blurring the normative boundaries between public art and private anatomy/medicine, as well as by confusing the conventional distinction between commercial marketing and medical humanitarianism. ${ }^{48}$ For Toscani, who regarded the David Kirby image as the most significant of those he designed for Benetton's 'Shock of Reality' advertising campaign of 1992, ${ }^{49}$ it was supposed to show how an

\footnotetext{
${ }^{46}$ See, for example, the AIDS posters reproduced in Sander Gilman, Picturing Health and Illness: Images of Identity and Difference (Baltimore: Johns Hopkins, 1995), 124-8.

${ }^{47}$ For a statement on how Western medicine achieved and sustained this 'Biblical'-like position in the twentieth century, see David Armstrong, A New History of Identity: A Sociology of Medical

Knowledge (London: Palgrave, 2002). For how it lost it through the debate over HIV as the cause of AIDS, see Joan H. Fujimura and Danny Y. Chou, 'Dissent in Science: Styles of Scientific Practice and the Controversy Over the Cause of AIDS', Sociology of Science and Medicine, 38 (1994), 1017-36; Steven Epstein, Impure Science: AIDS, Activism, and the
}

Politics of Knowledge (Berkeley: University of California Press, 1996). Subsequently, it was biomedicine in general, rather than the medical profession in particular, that came to define 'life'-see Nikolas Rose, The Politics of Life Itself: Biomedicine, Power and Subjectivity in the TwentyFirst Century (Princeton: Princeton University Press, 2007).

${ }^{48}$ See Cooter and Stein, op. cit. (note 15).

${ }^{49}$ The campaign cost 70 million US dollars. See Torsten Sevecke, Wettbewerbsrecht und Kommunikationsgrundrechte: Zur rechtlichen Bewertung gesellschaftskritischer Aufmerksamkeitswerbung in der Presse und auf Plakaten am Beispiel der Benetton-Kampagnen, 


\section{Claudia Stein and Roger Cooter}

international corporation was 'open to the world's influences and engaged in a continuing quest for new frontiers' ${ }^{50}$ For him, this meant commitment to global social issues, above all, to the problems of poverty, race and disease. However, this was far from how the image was regarded by others. Although in different contexts reactions varied, overall it was greeted with howls of moral indignation and in some places to the sacking of Benetton shops. The Germans took the image to court, French billstickers refused to post it and, in Britain, The Guardian (the first newspaper to run it as a full-page advertisement) was inundated with letters of complaint. ${ }^{51}$ Nor was that all. While many in the gay community responded to it favourably, others criticised it as a form of cultural and economic imperialism. The critique fed a form of political resistance known as 'culture jamming', or 'adbusting' that hijacks the ads of big brands to talk back to them in order to re-conquer city space. ${ }^{52}$ Toscani's image immediately became the victim of this 'Semiotic Robin Hoodism': the American AIDS Coalition to Unleash Power (ACT UP) 'piggybacked' on it, writing beneath it, 'There's only one pullover this photograph should be used to sell' - and pictured a condom. ${ }^{53}$ Here, supposedly, was the subconscious of the Benetton campaign X-rayed to uncover not only its opposite meaning, but also (in the manner of Sontag's analysis) to reveal a deeper truth ostensibly lurking beneath the layers of advertisement euphemism. $^{54}$

Here, then, was yet another field of combat over the meaning of HIV/AIDS centred on its imagery. But, again, there was no hint of it at the show in Hamburg. While Toscani's image still had the power to shock, it is doubtful if anyone outside of living memory who viewed it at the exhibition (such as the school children bussed in) could have guessed what it meant for many visual theorists and AIDS activists worrying over images of AIDS since the late 1980s, namely, that it was further testimony to the ongoing 'crisis over the entire framing of knowledge about the human body', 55 with AIDS, not just a 'medical' problem but 'an epidemic of meanings or significations'. 56 The exhibition in Hamburg gave no clue to how images like this had been regarded as

(Baden-Baden: Nomos Verlagsgesellschaft, Band 14, 1997), 24.

${ }^{50}$ Joan Gibbons, 'Reality Bites', Chapter 4 of Art and Advertising (London: I.B. Tauris, 2005), 75-96.

${ }^{51}$ The reactions were overviewed in 'Benetton-Advertising History' entry for 1992, online: http://www.ucad.fr/pubgb/virt/mp/benetton/ pub_benetton.html, accessed 16 March 2003. See also Döring, op. cit. (note 9), 128-9. The Guardian was forced to defend itself in an editorial of 24 January 1992; see Lorella Pagnucco Salvemini, United

Colours: The Benetton Campaigns (London:

Scriptum Editions, 2002), 92-3.

${ }^{52}$ Naomi Klein, No Logo: Taking Aim at the Brand Bullies (London: Flamingo, 2000), 279-309; Kalle Lasn, Culture Jam: How to Reverse America's Suicidal Consumer Binge-and Why We Must (New York: HarperCollins, 1999). The term 'culture jamming' was coined in 1984 by the San Francisco audio-collage band Negativland.

${ }^{53}$ The image is reproduced in Francis Beckett,

'Protest Politics', AIDS Matters, 8 (1992), 5.

${ }^{54}$ Klein, op. cit. (note 52), 281-2.

${ }^{55}$ Watney, quoted in Gilman, op. cit. (note 46), 115; see also 'The Rhetoric of AIDS: A Dossier Compiled by Simon Watney, with Photographs by Sunil Gupta', Screen, 27 (1986), 72-85; Douglas Crimp, 'Portraits of People With AIDS' in Crimp, Melancholia and Moralism: Essays on AIDS and Queer Politics (Cambridge, MA: MIT Press, 1992).

${ }^{56}$ Paula A. Treichler, 'AIDS, Homophobia, and Biomedical Discourse: An Epidemic of

Signification', Cultural Studies, 1 (1987), 263-305: 263-4. The essay is reprinted in her How to Have

Theory in an Epidemic: Cultural Chronicles of AIDS (Durham: Duke University Press, 1999). 
testifying to a self-consciously postmodern culture, ethics, aesthetics, disease representation, and politics of identity. Nor was the reproduction of Toscani's image at the Hamburg exhibition intended to illustrate how the lines between 'the commercial' and 'the medical humanitarian' had become so obscured that there was now little to mark the difference between a 'health poster' and an advertisement for the sale of fashion knitwear. Instead, despite the fact that many of the images in the Hamburg show had been designed simply to sell condoms, and others, such as that on homophobia, to 'challenge social injustice, prejudice and exclusion' rather than caution against HIV/AIDS itself, ${ }^{57}$ the exhibition cohered them all into a would-be historically uniform and medically mediated message against HIV/AIDS. Thus-although not with conscious intent - the show flew in the face of the preoccupations of the visual theorists and AIDS activists of the 1980s and 1990s. Where they had seen in representations of AIDS the postmodern play of signifiers, had argued for a plurality of subjectivities involved in visual engagements, and had construed visual perceptions of the human body in general as involving an onlooker's unconscious construction of their own body through the immediate act of viewing, the curators of the Hamburg exhibition saw only medicine and art in modernity.

This was not the only way in which the exhibition displaced the specific and general historical meanings attached to these objects by investing them with others. The title alone of the exhibition, 'Against Aids: Posters from Around the World' did as much. First and foremost it constructed a particular framework for their perception, one that above all suggested that aesthetic form can travel the world regardless of local geographies and local histories of ethnicity, religion, race, rights, sexuality and gender-not to mention alternative aesthetic traditions. This global aesthetic spin, in effect, harmonised a modernist Western transcendent notion of 'art' with the late twentieth-century notion of a spatially transcendent capitalism-an economic system supposedly unfettered by place or national boundary. ${ }^{58}$ The aesthetic spin and the exhibition as a whole thus further performed for notions of homogeneity and universality - attributes long associated with modernity and perceived to be at odds with the pluralities and fragmentations associated with postmodernity during the 'time of AIDS' in the West. ${ }^{59}$

The exhibition's title also suggested that the history of AIDS was about everyone the world over being uniformly against AIDS. But that, too, was hardly the case at the point of production of many of these posters. In the 1980s, Christian fundamentalists and other religionists took a rather different line, and gay men and lesbians did not always

\footnotetext{
57 “'It's Prejudice That's Queer"-Questions and Answers: For Internal Use by CHAPS/THT Staff Only', Terrence Higgins Trust internal memo, cited by permission of the Terrence Higgins Trust.

${ }^{58} \mathrm{On}$ the increasing disconnection of the global marketplace from national politics, see Naomi Klein, The Shock Doctrine: The Rise of Disaster Capitalism (London: Allan Lane, 2007); Ulrich Beck, Was ist Globalisierung? Irrtumer des

Globalismus-Antworten auf Globalisierung
}

(Frankfurt: Suhrkamp, 2007)—who regards 'the global' as forwarded by liberal democracies in the course of their decline as politically autonomous nation states; John Ralston Saul, The Collapse of Globalism and the Reinvention of the World (London: Atlantic Books, 2005); Arjun Appadurai, 'Grassroots Globalisation and the Research Imagination,' in idem (ed.) Globalisation, Durhan and (London: Duke University Press, 2001), 4.

${ }^{59}$ See Christopher Bayly, The Birth of the Modern World, 1780-1914 (Oxford: Blackwell, 2004), 1-12. 


\section{Claudia Stein and Roger Cooter}

see government campaigns against AIDS as being against AIDS so much as against themselves. ${ }^{60}$ As noted above, in Thatcher's Britain the AIDS campaign was an occasion for the moral high-grounding of heterosexual values. ${ }^{61}$ To the extent that people (and international pharmaceutical companies) were allegedly 'against AIDS' in the 1980s and 1990s, their concerns emerged from a multitude of different and often conflicting social and economic interests. Moreover, the relative power of those interests was hierarchically organised, and differently so over time, as Virginia Berridge has made clear for the history of AIDS in the UK. ${ }^{62}$

Also, implicit to the entitling of the Hamburg exhibition was the idea that nations around the world were homogeneous in their fight against HIV/AIDS. This not only collapsed separate national encounters with HIV/AIDS, such as its very denial by South Africa's President Thabo Mbeki, but effaced the differences between the kinds of media campaigns used in different countries-including the often bitter struggles between local, national and international agencies. ${ }^{63}$ As important, this political gutting of AIDS posters through their aestheticisation erased national rivalries and pressures involved in medically treating AIDS victims (or not, as the case may be). Through the mixing of posters from different countries, the exhibition dissolved the conventional boundaries between nation-states, while the multitude of images of condoms that it presented served visually to re-unite them around a commercial product. The images of condoms promoted the idea that campaigns for their use had actually united the countries of the world, a message curiously at odds with the Bush administration's contemporaneous funding of medical missionaries advocating sexual abstinence instead of the use of condoms. ${ }^{64}$ In its own small way, therefore, and for its own particular didactic reasons (as well as, perhaps, discomfort over Germany's nationalistic past), the Hamburg exhibition effected the same kind of historical effacement and rewrite that the major international media and entertainment companies were also coming to effect by 2006 through their take of up HIV/AIDS for the purpose of reaping public corporate credibility. ${ }^{65}$ By then, HIV/AIDS-funding was a fashionable cause, a benign branding resource for various Western philanthropic organisations.

\footnotetext{
${ }^{60}$ Watney, op. cit. (note 43); for biomedicine's role in this, see Michael Lynch, 'Living with Kaposi's Sarcoma and AIDS', Body Politic, 88 (1982), 31-7.

${ }^{61}$ Watney, ibid:; Philip Gatter, Identity and Sexuality: AIDS in Britain in the 1990s (London: Cassell, 1999), 82ff; Virginia Berridge, AIDS in the UK: The Making of Policy, 1981-1994 (Oxford: Oxford University Press, 1996), 56.

${ }^{62}$ Berridge, ibid., shows that over the twenty-odd years since the syndrome first surfaced in the UK, there were at least four distinct phases to those power relations and their representations.

${ }^{63}$ Peter Baldwin, Disease and Democracy: The Industrialized World Faces AIDS (Berkeley: University of California Press, 2005); see also Cristiana Bastos, Global Reponses to AIDS: Science in Emergency (Bloomington: Indiana University Press, 1999); Laurie Garrett, Betrayal of Trust: The Collapse of Global Public Health (New
}

York: Hyperion, 2000); Colleen O'Manique, Neoliberalism and AIDS Crisis in Sub-Saharan Africa: Globalisation's Pandemic (London: Palgrave, 2004).

${ }^{64}$ Elizabeth Pisani, The Wisdom of Whores: Bureaucrats, Brothels and the Business of AIDS (London: Granta, 2008).

${ }^{65}$ For instance, at the XVI International AIDS conference on 14 August 2006, Bill Roedy, the Chairman of Global Media AIDS Initiative-also President of MTV Network International-gloated over the public relations benefits to industries involved in such work. 'Media have such a huge role to play in this fight', he said, 'and as a member of the media industry I can fully admit we're not doing enough. (applause). Media can actually be a force of the good. When is the last time you have heard media can be a force of the good? Well, here media can be a force of the good.' Online: http://www.kaisernetwork. 
At local, national and transnational levels then, 'Against Aids: Posters from Around the World' can be seen to have effaced the individual history of the objects on display through a particular universalising and seemingly neutral kind of aestheticisation. At a closer look, however, it both appropriated them into an old script (a local and fondly held modernist epistemology of viewing and aesthetics) and a new one-globalisation. By collapsing two decades of national histories into a singular and would-be unified world fight against HIV/AIDS, the history of HIV/AIDS was visually construed in terms of this new global subjectivity. Not only were particular constructions of the recent past left out - the local struggles around these objects-but also the construction of the present-the global media industry's selling of itself through the attack on HIV/AIDS as a 'global problem'. Thereby, 'globalisation' was not only made 'real' or made 'true' through aesthetic representation of an ostensibly international struggle against HIV/ AIDS, but by this same conceit was medically re-appropriated and humanised-no matter that over the meaning of 'globalisation' there has been little agreement, let alone consensus on it as a 'good thing'. 66

This is not to suggest that HIV/AIDS was not recognised as a global problem almost from its start. In 1987, the American AIDS activist, feminist and visual theorist, Paula Treichler, for instance, referred to AIDS as having 'a potential for global devastation'. ${ }^{67}$ But for her and others in the 1980s 'the global' was only a background problem, and the term was yet without particular epistemic load. As we have indicated, Western nations and their intellectuals and AIDS activists were gripped more by their own campaigns, interests, and ideologies than by 'global' concerns. In fact, the idea in the West that HIV/AIDS was a 'global problem' was a viewpoint that itself had to be fought for through a world wide media campaign brokered by organisations with internationalist interests. The campaign can be dated precisely to 27 May 1987 when the World Health Organisation issued a press release proclaiming that 'AIDS is a global epidemic that demands a global attack'. ${ }^{68}$ The WHO then produced a poster to sell the message (Figure 6) - to compete, that is, with other struggles for the meaning of AIDS. ${ }^{69}$ The Hamburg exhibition abetted that project through a visual rhetoric of shared international struggle against HIV/AIDS, just as it unwittingly abetted the subsequent take over of AIDS programs by the media multinationals. ${ }^{70}$ Thus it eclipsed

org/health_cast/uploaded/files/

081406_ias_media_transcript.pdf, 11.

${ }^{66}$ Ong and Collier, op. cit. (note 12), 3.

${ }^{67}$ Treichler, op. cit. (note 56), 263.

68 'World Health Organization Launches Public Information Effort to Increase Global Awareness of AIDS', WHO Press, Press release WHO/15, 27 May 1987. Welcome Library. The message has been annually reiterated since December 1988 when the WHO initiated 'World AIDS Day'.

${ }^{69}$ By 1988 , when AIDS and its Metaphors was first published, Sontag could observe that at international congresses 'the global character of the AIDS crisis was a leading theme', and add wryly that in these forums 'the rhetoric of global responsibility' was naturally 'a specialty': Sontag, op. cit. (note 40), 91.

${ }^{70}$ While media multinationals came largely to constitute the Joint United Nations Program on HIV/ AIDS (UNAIDS, established in 1996), other giant multinationals-turned-philanthropic organisations, such as Gates and Viacom, in their independent AIDS programmes came to spend far more money than the UNAIDS: T. Tannen, 'Media Giant and Foundation Team Up to Fight HIV/AIDS', Lancet, 361, (26 April 2003), 1440-1; UNAIDS, 'The Joint United Nations Programme on HIV/AIDS (UNAIDS)', 12 August 2005, online: http://www.thebody.com/uniads/ unaidspage.html. 


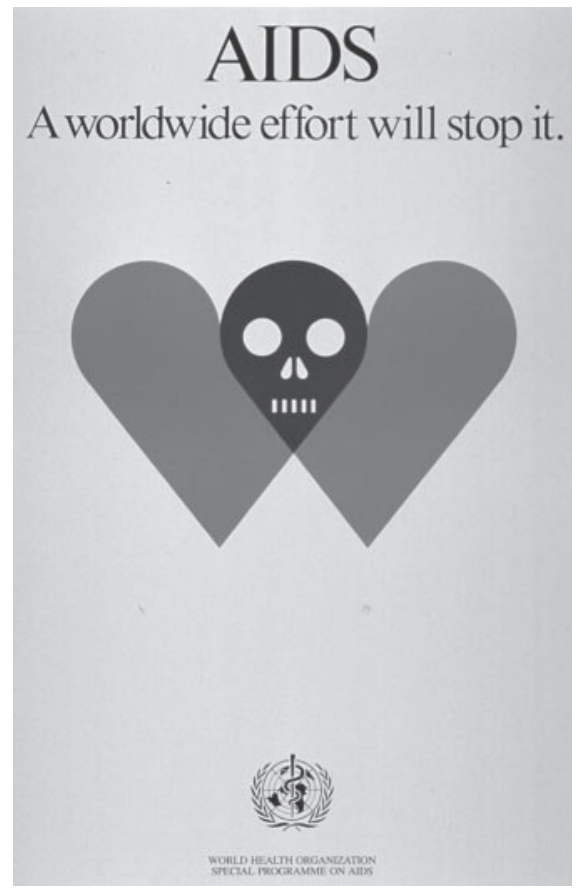

Figure 6: WHO poster of $1987(91 \times 61 \mathrm{~cm})$ selling AIDS as a global phenomenon. Courtesy of the National Library of Medicine, USA. This poster was also translated into many languages.

the history that would enable anyone to believe that AIDS had ever been anything other than 'global', or for that matter, anything other than mainly a struggle for economic resources for better medical provision for victims of the condition. Images intended for, and often produced by, local sub-groups became artefacts for making up global citizens, with 'the global' and 'global citizenship' simply assumed to be good things. Thereby, the exhibition did far more than merely reinforce what had become the 'semantic hegemony' of 'the global', as iterated through such credulities as 'global warming' and 'global terrorism'. ${ }^{71}$ Through aesthetics alone it rendered tangible the universalising concept of the global. 'The global' became something to experience, identify with, and embrace. Although this was not the exhibition's primary intention, it could not help but perform it, and in so doing contribute to a reconstruction of history and consciousness. There was no conspiracy in this. Far from it; the globally spun institution-serving celebration of the aesthetics of AIDS posters merely reflected and reinforced much of what everybody in the West had already come to 'feel' about HIV/AIDS by 2006 - that it was a serious world-wide problem about which everyone needed to be continually reminded.

\footnotetext{
${ }^{71}$ On the 'semantic hegemony', see Beck, op. cit. (note 58).
} 


\section{Conclusion}

We have been concerned with a particular moment in the history of AIDS posters: not that of their initial 'public' life on the streets, or in pubs and gay clubs, doctors offices, and so on, but their 'afterlife' in places where they might be displayed or stored. $^{72}$ Through the analysis of an exhibition at one such afterlife location our intention has not been that of negative dismissal, nor critique for the sake of it. Nor has it been merely to expose how these often strikingly visual objects that aimed at protecting individual health had their meaning changed through appropriation into a conceptual framework different from that of their initial contexts of production and consumption. More interesting to us are the intrinsic and unremitting links between these visual objects and wider politics, or how the visual is inherently a part of the latter.

While it might have been supposed that AIDS posters came to political rest once they were retired, categorised, catalogued and stored according to the principles of collecting institutions, the Hamburg exhibition proves otherwise. In fact, as collector's items, they entered a space that was no less political than when they were on the streets in the 1980s and 1990s, and when they were appropriated to Western discourses on postmodern identity and on the role of the visual in the cultural negotiation of the self. It could hardly be otherwise, for simply by entering such a 'retirement home' they necessarily became a part of the institutional agenda of the Museum für Kunst und Gewerbe. In effect, here, as elsewhere, they were 'framed' in agendaserving classificatory narratives embedded in bricks and mortar. Indeed, from the moment such objects become collectors' items and are stored and/or displayed as artifacts they become epistemologically loaded through the very process of objectification.

Hamburg's Museum für Kunst und Gewerbe demonstrates that these collecting agendas and the accompanying aesthetic guidelines often have deep historical roots. But what the analysis of its 2006 exhibition of AIDS posters also shows is that old and seemingly apolitical agendas (invented to express specific national political interests) are neither lost nor rendered innocuous in the contemporary world. Rather, they come to serve new political frameworks linked to the world of today's visitors-a world in which aesthetics is the dominant means to a politics constituted on little more than the idea that 'if it looks good go with it' (an outlook now as pervasive in the practice of science as in the arts of government). ${ }^{73}$ Crucially, this new politics is sustained through, and for, the absenting of critique; not today the critical outlook

\footnotetext{
${ }^{72}$ The former are not necessarily places more 'public' than the latter. Many AIDS posters, contrary to the impression lent them through exhibitions such as that in Hamburg, were never seen outside of gay pubs, clubs and toilets-and some were one-offs produced only for art shows. We only begin to think they were 'public' because the specific groups to whom they were often targeted are dissipated in the archive or in the museum. Implicitly in these places-designed, of course, for preserving 'public memory'-a new composite public is assembled for
}

them. On the vicissitudes and contradictions of 'the public' see Michael Warner, Publics and

Counterpublics (New York: Zone Books, 2005). On memory and history, see Geoffrey Cubitt, History and Memory (Manchester: Manchester University Press, 2007).

${ }^{73}$ For these politics in the practice of contemporary science, see Daston and Galison, op. cit (note 5), ch. 7: 'Representation to Presentation', 363-417. 


\section{Claudia Stein and Roger Cooter}

entertained by Sontag and other pre-postmodern intellectuals, that visual representations (and popular posters in particular) covered-up or cloaked lurking ideologies. Postmodernists, unconcerned with that view for the most part, in effect opened the space for the new politics of aesthetics that masks something different: the idea of aesthetics as void of political intention. The Hamburg exhibition of AIDS posters was, in fact, an early example of the coming-to-reign of these particular politics, with the visual alone being the vehicle for understanding and creating a ('global') community without distinction. Whereas for Brinckmann in the nineteenth century, aesthetics (in art) could be consciously used for the political purpose of populist democracy, with aesthetics and politics in clearly separate spheres, for the inheritors of his institution in Hamburg aesthetics (unbeknownst to them) became the politics, not simple a means to it. Ironically, their arrival at these politics-their unknowing performance of them through the exhibition-was via adherence to Brinckmann's legacy. Through that, Brinckmann's original political agenda was emptied of its original political purpose. Installed in its place were the politics of the appearance of political un-intention. Thus did an aesthetic concept born in the nineteenth century to serve nationalistic purposes come to operate for the political work of educating national citizens to global citizenship.

What does this mean for historians working with material objects stored in globaltending museums and archives and who are themselves now operating within a global framework? Since material objects have no meaning without a framework, and are framed in being collected, the simple answer is that historians have to take into account the afterlives of such objects as much as the object's original lives. Would that it were quite that simple, though. Harder is the problem of the historian's own place in 'the global framework', which, in many respects, is not unlike that of the material object in the global-aspiring museum (and very much like that of the curators of such exhibitions). Whether avowed explicitly in 'global history', or embraced implicitly in the practice of history writing in contemporary culture, 'the global' operates politically and epistemologically. Just as global history's predecessor 'world history' is now perceived by some of its originators as having been a product of, and agent for, its Cold War moment, ${ }^{74}$ so for our own times, dominated as they are by multi-national corporations and abiding politicians, the take up of global themes in history writing is widely recognised as providing, at the very least, legitimacy to a globalisation discourse, even if, as often the case, the historian's immediate object is the far from reactionary one of provincialising the West and critiquing its hegemony. ${ }^{75}$ Of course, for some historians 'the global' does politically more, overtly serving as a rhetorical strategy for the re-coherence of the discipline of history itself after its pummelling by poststructuralists, deconstructionists and other fragmenting postmodern forces over the past thirty years or more. ${ }^{76}$ To this end, what could serve better as a

\footnotetext{
${ }^{74}$ William H. McNeill, 'The Rise of the West after Twenty-five Years', Journal of World History, 1 (1990), 1-21.

${ }^{75}$ See, for example, James M. Blaut et al., 1492: The Debate on Colonialism, Eurocentrism, and History (Trenton: Africa World Press, 1992); and
}

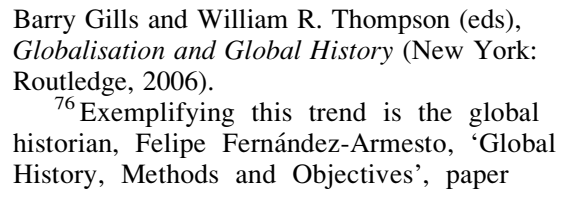




\section{Visual Objects and Universal Meanings}

reunifying device than the holising connective metaphor of the globe? Thus the global provides a new grand narrative - a universalising tool-with which to reimpose the meta-narrativity of history. Although seemingly mindless of one of postmodernism's cautions, that totalising worldviews can lead to totalitarianism, ${ }^{77}$ these historians seek more-or-less intentionally what the curators of the Museum für Kunst und Gewerbe performed innocently through their exhibition of AIDS posters. In so doing, they also share company with certain art historians anxious to revive older agendas-a means (as bluntly put by one of them) to counter the 'deconstructive criticism of historical culture' proposed by 'self-serving postmodern academics' who treat the past as 'a sour land over which to exercise present concerns and anxieties'. ${ }^{78}$ Yet neither global history nor visual culture studies need necessarily lead in this direction. To see the global as a discourse tied politically to institutionally specific agendas (such as the aesthetics entertained at the Museum für Kunst und Gewerbe in Hamburg in 2006) offers the possibility to take an alternative political position, or at least to liberate its historical study from such agendas.

Nevertheless, in terms of the less-visible shaping of historical knowledge production, the global framework can never be other than 'world-making' as opposed to being simply historically descriptive. ${ }^{79}$ No matter how hard we try to stick to the recovery of some truth of how the world came to be globally conceived (past or present), our knowledge productions implicitly reproduce and foster the unifying construct. Just as with material objects (or words or images) there is no meaning to historical events outside the conceptual frameworks we wittingly or unwittingly apply to them. In short, there exists no resting place for history writing; it is always already fashioned and fashioning. Like creating a museum exhibition of posters to aestheticise the 'global' nature of HIV/ AIDS, the business of contributing to a global history of anything entails, by that very act, the politics of constructing a necessarily partial representation of 'the past'. History writing, too, in other words, as a product of its time, cannot avoid making up historical consciousness.

This article cannot escape the charge that it too contributes to this process merely by discussing an event that was conceptualised in 'global' terms. It might even be seen to compound the problem by drawing attention to spaces where, a priori, the historian is already politically and epistemologically implicated: the museum and the archive. However, in doing so it has sought to move the discussion beyond the tired call for attending merely to historical contexts, especially of material objects globally attributed. Our

presented to the Polyphonic History Seminar, Madrid, 22 January 2008. On the effects of the postmodern turn in medical history, see Roger Cooter, "After Death/After-"Life": The Social History of Medicine in Post-Postmodernity', Social History of Medicine, 20 (2007), 441-64; Roger Cooter, 'The Turn of the Body: History and the Politics of the Corporeal', Arbor Ciencia, Pensamiento cultura, 186 (2010), 393-405.

${ }^{77}$ Chris Hables Gray, Cyborg Citizen: Politics in the Posthuman Age (New York: Routledge, 2001), 17.

\footnotetext{
${ }^{78}$ Martin Kemp, Seen/Unseen: Art, Science, and Intuition from Leonardo to the Hubble Telescope (Oxford: Oxford University Press, 2006), 2. For Kemp, who seeks to reconstruct 'some continuities and discontinuities between past and present', history stands for itself, rather than a product of its times.

${ }^{79}$ Aruf Dirlik, 'Confounding Metaphors, Inventions of the World: What is World History For?' in Benedikt Stuchtey and Eckhardt Fuchs (eds), Writing World History, 1800-2000 (Oxford: Oxford University Press, 2003), 91-133: 92.
} 


\section{Claudia Stein and Roger Cooter}

purpose has been to encourage historians to an awareness of their own immediate entanglements in history's constructedness - the constructedness of the present mediated in history writing as much as through aesthetic assemblages of 'the global'. The historian Aruf Dirlik, critically inquiring into the point of writing world history, has observed that 'an awareness of the variety of world histories that have been constructed at different times and in different places... [must cause] any world historian worthy of the name... [to ] be uncommonly aware of the constructedness of the past. ${ }^{80}$ Similarly, we submit, all historians need be reflective on their contributions to the present- that is, to a culture given to re-enchantment through 'the global'. Quite how we should historicise material objects of the sort discussed in this paper may be open to debate; what is not is the necessity to historicise our own historical projects. Otherwise we move perilously close to becoming blind participants in the historically fashioned spaces where memory is increasingly naturalised and neutralised through universalised and universalising concepts mediated aesthetically. We end up, as it were, naïve viewers of the exhibition at Hamburg: as blind to the nature of the new post-postmodern politics of aesthetics, as to the modernist would-be universal humanity that 'the global' unwittingly espouses through those politics.

\section{Acknowledgements}

We owe special thanks to Renate Stein for alerting us to the exhibition at the Museum für Kunst und Gewerbe in Hamburg. Also to Jürgen Döring, the director of its department of graphic design and posters, and curator Hendrik Lunganini, for supplying us with information, photographs and other materials for our analysis. For much the same we are grateful to Sir Nick Partridge of the Terrence Higgins Trust. For valuable critical commentary we would like to thank Stephen Casper, Guy Attewell, Michael Laycock, Paolo Pallidino, and two anonymous referees. As always, we are lastingly obliged to the Wellcome Trust for its generous support.

${ }^{80}$ Ibid., 91 